\title{
Upadłość jednoosobowego przedsiębiorcy z możliwością oddłużenia a upadłość konsumencka byłego przedsiębiorcy - wybrane zagadnienia
}

\section{JEL classification: K35}

Słowa kluczowe: ogłoszenie upadłości, upadłość konsumencka, osoba fizyczna prowadząca działalność gospodarczą, oddłużenie przedsiębiorcy

Keywords: bankruptcy, consumer bankruptcy, natural person conducting a single-person business, debt cancellation

\begin{abstract}
Abstrakt: Możliwość umorzenia zobowiązań osoby fizycznej prowadzącej jednoosobową działalność gospodarczą stanowi przedmiot szerokiej debaty w środowiskach zarówno prawniczych, biznesowych, jak i akademickich. Tak zwany nowy start nierzadko jawi się dla wielu zadłużonych, obecnych lub byłych, przedsiębiorców indywidualnych jako najbardziej pożądany scenariusz pozwalający na uwolnienie się od ciążących zobowiązań. Ostatnie nowelizacje ustawy Prawo upadłościowe sprawiły, że wielu mniejszych uczestników obrotu gospodarczego coraz częściej rozważa bądź to ogłoszenie upadłości na podstawie art. 20 i n. p.u. (licząc na możliwość oddłużenia), bądź też po wyrejestrowaniu z właściwego rejestru ogłasza upadłość konsumencką. Z pewnością warta uwagi jest w tym kontekście analiza poglądów przedstawicieli doktryny oraz najnowszego orzecznictwa.
\end{abstract}

\section{Bankruptcy of a single trader with the possibility of debt relief and consumer bankruptcy of a former entrepreneur - selected issues}

\footnotetext{
Abstract: The ability to cancel the debts of a natural person derived from a single-person business activity is a matter of broad debate in legal and business environments as well as academic. The so-called "fresh start" is perceived by many indebted, present or former individual entrepreneurs, as the most desirable scenario to free themselves from the existing obligations. The recent amendments to the polish Bankruptcy Law have made many smaller business participants increasingly consider either bankruptcy on the grounds of Article 20 et seq. of the Bankruptcy Law (counting on the possibility of debt cancellation) or, after deregistration from the relevant register,
} 
the inferencing for consumer bankruptcy. In the light of the aforementioned issues it is of crucial importance to analyze the views of the representatives of the doctrine as well as recent case law.

\section{Wstęp}

Nowelizacja ustawy Prawo upadłościowe i naprawcze (tytuł ustawy otrzymał brzmienie Prawo upadłościowe; dalej: p.u. $)^{1}$ dokonana ustawą Prawo restrukturyzacyjne $^{2}$ wraz ze zmianami nieco wcześniej zaprowadzonymi ustawą nowelizującą z $2014 \mathrm{r}^{3}{ }^{3}$ zmieniającą zasady upadłości konsumenckiej łącznie stanowią wyraźny ukłon w kierunku przedsiębiorcy indywidualnego i wpisują się w trend, któremu przyświeca oddłużenie, czyli tak zwany nowy start ${ }^{4}$. Należy zaznaczyć, że zwiększająca się świadomość prawna podmiotów rynkowych, także tych prowadzących działalność w najmniej sformalizowanej formie — przez dokonanie wpisu do Centralnej Ewidencji i Informacji o Działalności Gospodarczej (CEIDG) ${ }^{5}$, jest obecnie skorelowana z wzrastającą liczbą wniosków o upadłość. Pośrednio umożliwia to jednak przede wszystkim reakcja ustawodawcy, która stanowi wyjście naprzeciw trudnej sytuacji wielu przedsiębiorców na obecnym rynku.

Głównym celem postępowania upadłościowego jest zaspokojenie roszczeń wierzycieli w jak najwyższym stopniu (art. 2 p.u.), jednak, abstrahując od możliwości realizacji wskazanego celu także na gruncie prawa restrukturyzacyjnego, na płaszczyźnie p.u. w odniesieniu do osób fizycznych wyłania się jeszcze jeden autonomiczny cel polegający na możliwości oddłużenia ${ }^{6}$. Jeśli zatem osoba indywidualna prowadząca działalność gospodarczą spełni określone ustawą kryteria związane z jej rzetelnością jako dłużnika, ma szansę na umorzenie zadłużenia. Jak czytamy w uzasadnieniu do projektu ustawy nowelizującego p.u. ${ }^{7}$ : „oddłużenie to realizowane jest zarówno $\mathrm{w}$ ramach postępowania określonego w przepisach tytułu V części trzeciej (postępowanie upadłościowe wobec osób fizycznych nieprowadzących działalności gospodarczej [tj. upadłości konsumenckiej]), jak

${ }^{1}$ Ustawa z dnia 28 lutego 2003 r. Prawo upadłościowe, tekst jedn. Dz.U.2016.2171.

2 Ustawa z 15 maja 2015 r. Prawo restrukturyzacyjne, tekst jedn. Dz.U.2016.1574 ze zm.

${ }^{3}$ Ustawa z dnia 30 wrześnie 2014 r. o zmianie ustawy - Prawo upadłościowe i naprawcze, ustawy o Krajowym Rejestrze Sądowym oraz ustawy o kosztach sądowych w sprawach cywilnych, Dz.U.2014.1306.

${ }^{4}$ Reforma wpisująca się w tak zwaną politykę drugiej szansy wynikającą z zalecenia Komisji z 12 marca 2014 r. w sprawie nowego podejścia do niepowodzenia w działalności gospodarczej i niewypłacalności, Dz.Urz. UE Nr 74, s. 65.

5 Każda osoba wpisana do właściwego rejestru przedsiębiorców (CEIDG, KRS) podlega ustawie Prawo upadłościowe jako podmiot prowadzący działalność gospodarczą.

${ }^{6} \mathrm{~W}$ piśmiennictwie wskazuje się, że oddłużenie stanowi wyjątek od zasady maksymalizacji zaspokojenia wierzycieli. Zob. R. Adamus, Prawo upadtościowe. Komentarz, Warszawa 2016, s. 845.

7 Druk nr 2824 z dnia 9 października 2014 r. Rządowy projekt ustawy — Prawo restrukturyzacyjne wraz z uzasadnieniem, s. 65. 
i w postępowaniu wobec osób fizycznych będących przedsiębiorcami na zasadach określonych w art. 369 i art. 370 p.u.n.” (co odzwierciedla treść art. 1 ust. 1 pkt 4 p.u. oraz art. 2 ust. 1a p.u.).

Dotychczas wielokrotnie zwracano uwagę na niewielki udział jednoosobowych przedsiębiorców w procedurze upadłościowej bądź to ze względu na liczne przypadki oddalenia wniosków ze względu na brak majątku dłużnika wystarczającego do pokrycia kosztów postępowania (tak zwane ubóstwo masy), bądź też na brak wiedzy o treści z art. 21 p.u. lub lekceważenie wynikającego zeń obowiąz$\mathrm{ku}^{8}$. W przeciwieństwie do art. $491^{1}$ ust. 1 p.u., statuującego jedynie uprawnienie osoby fizycznej nieprowadzącej działalności gospodarczej, art. 21 p.u. nakłada obowiązek złożenia wniosku o ogłoszenie upadłości na każdy podmiot wpisany do CEIDG lub KRS w terminie trzydziestu dni od dnia, w którym wystąpiła podstawa do ogłoszenia upadłości ${ }^{9}$, niezależnie od faktycznego powierzenia prowadzenia działalności innej osobie ${ }^{10}$ czy też późniejszych losów samego postępowania. W judykaturze podkreśla się, że „działalność gospodarcza w założeniu powinna być prowadzona w sposób profesjonalny i zawodowy, przy zachowaniu należytej staranności, złożenie zaś przez przedsiębiorcę w terminie wniosku o ogłoszenie upadłości jest w tym zakresie wymogiem o charakterze zupełnie podstawowym"11.

Literalnie odpowiedzialność odszkodowawcza za niezłożenie lub nieterminowe złożenie wniosku dotyczy wszystkich podmiotów zobowiązanych, jednak wyraźne sformułowanie tejże sankcji największe znaczenie praktyczne zyskuje w stosunku do osób prawnych i jednostek organizacyjnych nieposiadających osobowości prawnej, jako że osoby fizyczne i tak odpowiadają całym swoim majątkiem za zaciągnięte zobowiązania ${ }^{12}$. Oprócz odpowiedzialności cywilnej oraz

${ }^{8}$ Nieświadomość dłużnika co do obowiązku złożenia wniosku oceniana jest co najmniej w kategoriach niedbalstwa (winy nieumyślnej). Zob. postanowienie SO w Bydgoszczy z dnia 12 maja 2016 r., VIII Gz 42/16, System Analizy Orzeczeń Sądowych nr 225902.

9 Ustawa Prawo restrukturyzacyjne termin do złożenia wniosku o ogłoszenie upadłości wydłużyła z dwóch tygodni do jednego miesiąca, co miało na celu urealnienie obowiązku dłużnika. W uzasadnieniu do projektu czytamy, że termin 14 dni sprawiał, iż w praktyce nie zdarzały się wnioski złożone w terminie. Zob. druk nr 2824, s. 68.

10 Tak m.in. SO w Częstochowie w postanowieniu z dnia 25 listopada 2016 r., V Gz 209/16, System Analizy Orzeczeń Sądowych nr 261155, który podkreślił, że niezłożenie wniosku zgodnie z wymogiem art. 21 ust. 1 p.u. obciąża przedsiębiorcę, ponieważ jako osoba należycie dbająca o swoje interesy ponosi wszelkie konsekwencje związane z ryzykiem założonej działalności gospodarczej, zarówno w okresie jej prowadzenia, jak i po jej likwidacji.

11 Postanowienie SO w Bydgoszczy z dnia 12 maja 2016 r., VIII Gz 42/16, System Analizy Orzeczeń Sądowych nr 225902. Na temat konstytucyjności obowiązku zgłoszenia wniosku o upadłość zob. wyrok TK z dnia 4 lipca 2002 r., Dz.U.2002.113.990.

12 Przedsiębiorcy indywidualni coraz częściej decydują się na przekształcenie jednoosobowej działalności w spółkę z o.o. Samo przekształcenie nie jest jednak sposobem na uniknięcie spłacenia długów powstałych przed dniem przekształcenia (zob. m.in. art. $584^{13}$ k.s.h.). 
uprawnienia sądu do orzeczenia zakazu prowadzenia działalności gospodarczej lub pełnienia określonych funkcji do osób fizycznych nie mają zastosowania przepisy ustanawiające odpowiedzialność karną za niezłożenie w terminie wniosku o ogłoszenie upadłości (art. 586 k.s.h. ${ }^{13}$ ). W skrajnych sytuacjach nie należy jednak wykluczać odpowiedzialności karnej jednoosobowego przedsiębiorcy $\mathrm{w}$ wypadku wypełnienia znamion jednego z przestępstw przeciwko obrotowi gospodarczemu, w szczególności art. 301 § 3 k.k. (tak zwane karalne bankructwo) ${ }^{14}$ penalizującego lekkomyślne doprowadzenie do swojej niewypłacalności lub upadłości, w szczególności przez trwonienie części składowych majątku, zaciąganie zobowiązań lub zawieranie transakcji oczywiście sprzecznych z zasadami gospodarowania bądź też m.in. przestępstwa przeciwko mieniu z art. 286 k.k. (oszustwo), w wypadku świadomego zaciągania zobowiązań w braku jakichkolwiek zdolności do ich spłaty.

\section{Rzetelność przedsiębiorcy w świetle procedury oddłużenia}

Analizując okoliczności towarzyszące zachowaniu dłużnika, dodatkową i równie istotną konsekwencją niewłaściwego realizowania obowiązków przedsiębiorcy jednoosobowego (oprócz odpowiedzialności cywilnej czy zakazu prowadzenia działalności gospodarczej lub pełnienia określonych funkcji, orzekanego na okres od roku do dziesięciu lat), w tym niezłożenia lub nieterminowego złożenia wniosku o upadłość, jest trudność w skorzystaniu z istotnego przywileju — procedury oddłużeniowej. Tak zwany nowy początek (z ang. fresh start) służy uwolnieniu uczciwego dłużnika od całości lub części obciążeń, stanowiących zobowiązania niezaspokojone w postępowaniu upadłościowym. Jak już wspominano, umorzenie zobowiązań upadłego może dotyczyć jedynie dłużników będących osobami fizycznymi i ma miejsce po stwierdzeniu przez sąd zakończenia postępowania upadłościowego (gdy postępowanie upadłościowe zakończyło się zlikwidowaniem całego majątku upadłego) ${ }^{15}$. W przeciwnym wypadku, jeśli w wyniku likwidacji majątku upadłego nie zostaną zaspokojone wszystkie wierzytelności, a sąd nie przychyli się do wniosku w przedmiocie oddłużenia, upadły będzie narażony na borykanie się ze swoją przeszłością nie tylko przez kolejne lata, lecz nawet do końca życia. Oznacza to w szczególności konieczność kontynuowania egzekucji z dochodów z podjętej przez dłużnika pracy. Niektórzy autorzy zwracają uwagę, że takie zjawisko znacząco potęguje chęć podejmowa-

13 Ustawa z dnia 15 września 2000 r. Kodeks spółek handlowych, tekst jedn. Dz.U.2016.1578.

14 Ustawa z dnia 6 czerwca 1997 r. Kodeks karny, tekst jedn. Dz.U.2016.1137 ze zm.

15 Obecnie wniosek oddłużeniowy składa się w terminie trzydziestu dni od dnia obwieszczenia postanowienia o zakończeniu postępowania upadłościowego (nie ma przeszkód, aby wniosek taki złożyć już w toku postępowania). Do 1 stycznia 2016 r. wniosek o umorzenie musiał być złożony wraz z wnioskiem o ogłoszenie upadłości lub w toku postępowania, nie później niż przed wydaniem postanowienia o zakończeniu postępowania obejmującego likwidację majątku. 
nia działalności w starej strefie, aby uniknąć przeznaczenia części dochodów na dalsze zaspokajanie wierzycieli ${ }^{16}$.

W art. 369 ust. 2 p.u. ustawodawca wyraźnie wskazuje, że sąd oddala wniosek o ustalenie planu spłaty wierzycieli i umorzenie pozostałej części zobowiązań, które nie zostały zaspokojone w postępowaniu upadłościowym, ,jeżeli upadły doprowadził do swojej niewypłacalności lub istotnie zwiększył jej stopień umyślnie lub wskutek rażącego niedbalstwa" (przepis jest odpowiednikiem art. $491^{4}$ ust. 1 p.u. w upadłości konsumenckiej). Wskazanie przesłanki „rzetelności” dłużnika jest szczególnie istotne w świetle art. 2 ust. 1a p.u. (dodanego ustawą Prawo restrukturyzacyjne), w którym ustawodawca wskazuje, że „postępowanie uregulowane ustawą wobec osób fizycznych [prowadzących działalność gospodarczą] należy również prowadzić tak, aby rzetelny dłużnik uzyskał możliwość oddłużenia na zasadach określonych w ustawie". Owa rzetelność, i tym samym zachowanie dłużnika jako przedsiębiorcy, przedkłada się w dalszej perspektywie również na możliwość ogłoszenia upadłości konsumenckiej. Niewywiązanie się z określonych obowiązków czy też rażące niedbalstwo towarzyszące prowadzeniu działalności gospodarczej może okazać się fundamentalną przeszkodą w oddłużeniu niewypłacalnego obecnego lub byłego przedsiębiorcy. Należy mieć bowiem na względzie, że skorzystanie z beneficjum instytucji oddłużenia każdorazowo oznacza przełamanie zasady pacta sunt servanda i jednocześnie ingerencję w prawa wierzycieli.

Możliwość oddłużenia, która w stosunku do indywidualnego przedsiębiorcy rozpatrywana jest na wniosek ${ }^{17}$, wymaga zbadania wielu przesłanek. Nie każdy przedsiębiorca indywidualny może bowiem skorzystać z tak zwanej nowej szansy, a tylko ten, który spełnia cenzus „moralności płatniczej upadłego"18. Przytoczona treść art. 369 ust. 2 p.u. (przesłanki podmiotowe), w brzmieniu obowiązującym od dnia 1 stycznia 2016 r., znacząco zmieniła podejście do kwestii umarzania zobowiązań niewypłacalnych dłużników. Ustawodawca wskazuje pośrednio, że „umyślność” lub „rażące niedbalstwo” są równoznaczne z obrazem „nierzetelnego dłużnika”, który swoim działaniem krzywdzi wierzycieli. Zwiększenie świadomości prawnej pośród aktywnych uczestników rynkowych sprawia, że ustawodawca oczekuje, że niewypłacalny przedsiębiorca nie będzie ignorował nadmiernego zadłużenia czy też finansował swojego biznesu, podejmując nieracjonalne działania i pogłębiając swój stan niewypłacalności, m.in. uciekając

16 R. Lewandowski, P. Wołowski, Prawo upadłościowe i naprawcze, Warszawa 2011, s. 222 223.

17 Oznacza to, że w przedmiocie umorzenia sąd nie może orzekać z urzędu. Dodatkowo, zgodnie z zasadą ne ead iudex ultra petita partium sąd jest związany wnioskiem i nie może orzec ponad żądanie upadłego. Zob. S. Gurgul, Prawo upadłościowe. Prawo restrukturyzacyjne. Komentarz, Warszawa 2016, s. 764-765.

18 Zob. R. Adamus, op. cit., s. 846. 
się do kredytowania nierentownej działalności, wybiórczo zaspokajając wierzycieli czy też usuwając majątek spod egzekucji.

W związku z tym sąd upadłościowy oddala wniosek o oddłużenie w wypadku zawinionego doprowadzenia do upadłości. Umyślność w rozumieniu art. 369 ust. 2 p.u. (a także art. $491^{4}$ ust. 1 p.u.) można rozumieć jako „objęcie przez dłużnika zamiarem doprowadzenia do niewypłacalności albo jej pogłębienia", rażące zaś niedbalstwo (lekkomyślność) - jako „niedołożenie należytej staranności wymaganej w danych okolicznościach" ${ }^{\prime 19}$. P. Zimmerman wskazuje przy tym, że w wypadku przedsiębiorców ocena dopuszczalnego ryzyka gospodarczego nakazuje traktować przesłankę rażącego niedbalstwa węziej niż w wypadku konsumentów. Zgodnie z przeważającą w prawie prywatnym dwuelementową konstrukcją winy in casu wymagane jest badanie zarówno składnika subiektywnego (tj. winy sensu stricto, nastawienia psychicznego dłużnika), jak i obiektywnego (tj. bezprawności, przedmiotowej niewłaściwości zachowania). Tak szerokie ujęcie przyczynienia się upadłego $\mathrm{w}$ znacznym stopniu (umyślność lub rażące niedbalstwo) do niewypłacalności zastąpiło i tym samym objęło wyartykułowany w poprzednio obowiązującym brzmieniu art. 369 p.u. przypadek zaistnienia wyjątkowych i niezależnych od upadłego okoliczności losowych jako przyczyn owej niewypłacalności.

Możliwość umorzenia długów, oprócz okoliczności ogólnych wskazanych w art. 369 ust. 2 p.u., wyłączają także dalsze przesłanki negatywne (które należy rozpatrywać autonomicznie od zdarzeń normowanych w ust. 2$)^{20}$, w tym m.in. te stanowiące podstawę do orzeczenia zakazu prowadzenia działalności gospodarczej lub pełnienia określonych funkcji (art. 369 ust. 3 pkt 1 p.u.), przy czym zakaz orzekany na podstawie art. 373 oraz 374 p.u. jest niezależny od samego faktu złożenia wniosku o ogłoszenie upadłości ${ }^{21}$. W art. 373 p.u. po raz kolejny mowa jest o „rażącym niedbalstwie” rozumianym jako „stopień naganności postępowania drastycznie odbiegającego od modelu właściwego w danych warunkach zachowania się osoby zobowiązanej”"22. W art. 369 ust. 3 pkt 2 p.u. ustawodawca ponownie powołuje się na „rzetelność” upadłego dłużnika, tym razem w świetle obowiązków nałożonych na niego w postępowaniu upadłościowym, a w art. 369 ust. 3 pkt 3 p.u. ustanawia konieczność badania „należytej staranności”, je-

19 Zob. P. Zimmerman, Prawo upadłościowe. Prawo restrukturyzacyjne. Komentarz, Warszawa 2016, s. 723.

${ }^{20}$ Podobnie jak w kontekście upadłości konsumenckiej (art. $491^{4}$ ust. $2-4$ p.u.), do zaistnienia przeszkody do uwzględnienia wniosku w przedmiocie oddłużenia wystarczy wystąpienie choćby jednej okoliczności wymienionej w ust. 3 oraz niewystąpienie względów słuszności czy względów humanitarnych. Por. postanowienie SO w Częstochowie z dnia 15 lipca 2016 r., V Gz 123/16, System Analizy Orzeczeń Sądowych nr 247488.

21 Zob. m.in. postanowienie SN z dnia 23 marca 2006 r., IV CSK 35/2005, OSNC 2007/1/14; oraz postanowienie SN z dnia 29 października 2008 r., IV CSK 239/2008, OSNC-ZD 2009/3/67.

22 Wyrok SN z dnia 26 stycznia 2006 r., V CSK 90/2005, Lex nr 195430. 
śli w poprzednich postępowaniach upadłościowych (jeśli takie były) w okresie dziesięciu lat przed dniem złożenia wniosku o ogłoszenie upadłości dłużnikowi umorzono już część lub całość zobowiązań (tak zwana recydywa upadłościowa). Także z pozostałych przesłanek negatywnych art. 369 ust. 3 p.u., determinujących uwzględnienie lub oddalenie wniosku oddłużeniowego, wyłania się wymóg dochowania należytej staranności, m.in. w postaci rękojmi należytego wykonania planu spłaty wierzycieli. Dodatkową przesłanką stojącą w kontrze do obrazu „rzetelnego dłużnika” jest wspomniane już we wstępie wybiórcze zaspokajanie wierzycieli i rozmaite czynności defraudacyjne, z tym że jeśli w okresie dziesięciu lat przed dniem złożenia wniosku o ogłoszenie upadłości taka czynność została prawomocnie uznana za dokonaną z pokrzywdzeniem wierzycieli (z reguły na podstawie art. 527 k.c. ${ }^{23}$ ), to jest to niemalże bezwzględny warunek oddalenia wniosku o umorzenie całości lub części niezaspokojonych zobowiązań.

Wszystkie wymienione tu dodatkowe przesłanki negatywne, torujące dostęp do beneficjum w postaci procedury oddłużeniowej, nie mają jednak charakteru absolutnego. Ustawodawca $w$ razie ewentualnych zaniechań czy podejmowania przez dłużnika „nierzetelnych” działań (a zatem zaistnienia negatywnych przesłanek niweczących uprawnienie do oddłużenia), zarówno w toku, jak i przed wszczęciem postępowania upadłościowego, wskazuje na możliwość umorzenia pozostałej po zakończeniu postępowania upadłościowego części zobowiązań, o ile jest to uzasadnione względami słuszności lub względami humanitarnymi (klauzula rozsądku) ${ }^{24}$. W odniesieniu do względów słuszności (norm moralnych, dobrych obyczajów) sąd bada zasadność działania dłużnika, biorąc pod uwagę warunki, w jakich przyszło mu działać. Z kolei względy humanitarne dotyczą oceny „okoliczności dotyczących osoby dłużnika"25, stopnia dotkliwości postępowania i jego wpływu na osobiste warunki dłużnika (w tym wysokiego stopnia biedy).

Ustawodawca wskazuje, że zmiana brzmienia art. 369 p.u. i dalszych przepisów związanych z możliwością oddłużenia osoby fizycznej prowadzącej działalność gospodarczą wynika z konieczności dostosowania jej do zmian związanych z tak zwaną upadłością konsumencką, ,gdyż byłoby nieuzasadnione tworzenie dwóch zupełnie odmiennych modeli oddłużania. Takich nadmiernych odmienności nie uzasadnia sam fakt prowadzenia działalności gospodarczej” ${ }^{26}$. Z całokształtu poprzedniej regulacji wyłaniał się znacznie bardziej wyjątkowy charakter instytucji oddłużeniowej, w związku z tym wielu dłużników pod rządami

23 Ustawa z dnia z dnia 23 kwietnia 1964 r. Kodeks cywilny, tekst jedn. Dz.U.2017.459.

24 „Są to tzw. klauzule generalne, pojęcia wartościujące, które dają sądowi pewną swobodę decyzyjną i odwołują się do wartości pozaprawnych". Zob. postanowienie SO w Częstochowie z dnia 30 czerwca 2016 r., V Gz 102/16, System Analizy Orzeczeń Sądowych nr 247487.

25 Ibidem.

26 Druk nr 2824, s. 89. 
obecnej ustawy ma nadzieję, że sądy znacznie przychylniej będą traktowały ideę „drugiej szansy” dla rzetelnych przedsiębiorców. W praktyce oznacza to, że ustawodawca eksponuje możliwość „,nowego startu” w ramach reżimu upadłości stworzonego dla przedsiębiorców, zniechęcając tym samym do nieprzemyślanego wyrejestrowywania działalności z CEIDG w celu natychmiastowego skorzystania ze znacznie mniej kosztownej i uproszczonej procedury przeznaczonej dla konsumentów. Takie działanie obarczone jest, co do zasady, wysokim ryzykiem i grozi oddaleniem przez sąd wniosku o upadłość konsumencką, o czym poniżej.

\section{Oddłużenie byłego przedsiębiorcy w upadłości konsumenckiej}

Upadłość konsumencka jako postępowanie sądowe przeznaczone dla osób fizycznych nieprowadzących działalności gospodarczej w zależności od biegu wypadków może obejmować również długi związane z prowadzoną wcześniej działalnością gospodarczą. Jedną z istotniejszych zmian w tym zakresie, która weszła w życie z dniem 1 stycznia 2016 r. ${ }^{27}$, jest uzyskanie konsumenckiej zdolności upadłościowej już następnego dnia po wykreśleniu z rejestru przedsiębiorców (co należy odróżnić od zaprzestania prowadzenia działalności gospodarczej, które jest zdarzeniem o charakterze faktycznym) ${ }^{28}$. Wynika to przede wszystkim ze zmiany treści art. 8 p.u., który utratę zdolności upadłościowej jako przedsiębiorcy wiązał z koniecznością upływu jednego roku od chwili wykreślenia z właściwego rejestru przedsiębiorców. Zgodnie zaś z art. $491^{1}$ p.u. postępowanie upadłościowe wobec osób fizycznych nieprowadzących działalności gospodarczej może toczyć się wyłącznie w trybie przepisów o upadłości konsumenckiej. Już zatem na drugi dzień po wykreśleniu z właściwego rejestru dłużników traktuje się jako nieposiadających zdolności upadłościowej jako przedsiębiorca. Obecne brzmienie art. 8 p.u. kreuje jedynie charakter uprawnienia po stronie wierzyciela, podczas gdy dłużnik ma już konsumencką zdolność upadłościową ${ }^{29}$. Decydując się na taki kierunek nowelizacji, jednocześnie zachowano cel przepisu, jakim było uniemożliwienie ucieczki przedsiębiorcy przed ogłoszeniem upadłości przez wykreślenie z CEIDG bądź też wyjście naprzeciw sytuacji, gdy przesłanki niewypłacalności związane z prowadzoną działalnością gospodarczą ziszczą się dopiero po jej zaprzestaniu $^{30}$.

27 Wprowadzona ustawą z dnia 15 maja 2015 r. Prawo restrukturyzacyjne, tekst jedn. Dz.U.2016.1574 ze zm.

${ }^{28}$ P. Zimmerman, op. cit., s. 16.

${ }^{29}$ Ibidem. Postępowanie zainicjowane przez wierzyciela po wyrejestrowaniu z CEIDG może toczyć się jedynie w trybie przepisów o upadłości konsumenckiej. Przeciwny wniosek byłby sprzeczny z konstrukcją przepisów ogólnych p.u. R. Adamus, op. cit., s. 48, mówi tu o „hybrydalnej upadłości konsumenckiej z wniosku wierzyciela".

${ }^{30}$ R. Adamus, Komentarz do art. 8 p.u., [w:] Prawo upadtościowe i naprawcze, red. A. Witosz, A.J. Witosz, Warszawa 2014, s. 73. 
W świetle powyższego można wyróżnić dwa podstawowe przypadki, w których dojdzie do rozstrzygania przez sąd o zadłużeniu byłego przedsiębiorcy tuż po wyrejestrowaniu działalności z CEIDG. Przede wszystkim będzie to sytuacja, w której sąd na podstawie art. 13 ust. 1 p.u. oddalił wniosek o upadłość złożony przez przedsiębiorcę w trybie art. 20 i n. p.u. w związku z tak zwanym ubóstwem masy (brak majątku na pokrycie kosztów postępowania upadłościowego) ${ }^{31}$ bądź też po zakończeniu podstępowania upadłościowego nie zgłoszono w wymaganym terminie wniosku o umorzenie pozostałych zobowiązań. Wówczas tuż po wyrejestrowaniu działalności z CEIDG były przedsiębiorca ma prawo sięgnąć po tak zwaną upadłość konsumencką, wskazując przy tym, że dokonał wszelkiej staranności związanej ze złożeniem wniosku o upadłość jako indywidualny przedsiębiorca. Drugi przypadek to gdy przedsiębiorca zaniecha złożenia wniosku o upadłość przedsiębiorcy bądź też złożył wniosek spóźniony (nie uzyskując umorzenia pozostałych zobowiązań), decydując się na wykreślenie działalności z CEIDG w celu natychmiastowego złożenia wniosku o upadłość konsumencką ${ }^{32}$.

W obu wymienionych sytuacjach uczciwe i zgodne z prawem postępowanie oraz rzetelność niewypłacalnego przedsiębiorcy ma fundamentalne znaczenie dla możliwości ogłoszenia upadłości konsumenckiej (i tym samym oddłużenia). $\mathrm{W}$ przeciwieństwie jednak do ustawowego obowiązku wynikającego z art. 23 p.u. złożenie wniosku przez osobę nieprowadzącą działalności gospodarczej stanowi przywilej umożliwiający całkowite zwolnienie konsumenta $z$ długów ${ }^{33}$. Jak czytamy w uzasadnieniu rządowego projektu ustawy nowelizującej prawo upadłościowe:

na gruncie nowych przepisów o upadłości konsumenckiej umorzenie postępowania wobec [...] dłużników ma [...] być możliwe wyłącznie w przypadkach związanych z jego nierzetelnością i mieć charakter penalizujący takie zachowania [...]. Na gruncie dotychczasowych przepisów w związku ze stosowaniem art. 361 p.u.n. umorzenie było natomiast możliwe w razie ubóstwa masy czy na wspólne żądanie wszystkich wierzycieli. W przypadkach takich nie ma żadnych powodów, żeby uniemożliwiać dłużnikowi dostęp do oddłużenia według przepisów o upadłości konsumenckiej ${ }^{34}$.

31 W orzecznictwie wskazano, że brak majątku na pokrycie kosztów postępowania upadłościowego podlega ocenie sądu w toku postępowania, stąd też kwestia uwzględniania bądź oddalenia wniosku nie powinna być z góry antycypowana. R. Adamus, Komentarz do art. 8 p.u., s. 73. Zob. także wyrok WSA w Warszawie z dnia 2 grudnia 2009 r., III SA/Wa 1136/2009, LEX nr 550190; oraz wyrok SO w Gliwicach z dnia 27 maja 2013 r., X Gz 97/13, niepubl., w którym sąd podkreślił, że jeśli majątek dłużnika wystarcza co najwyżej na pokrycie kosztów postępowania upadłościowego, to postępowanie to nie będzie służyło interesom wierzycieli.

32 Zob. postanowienie SO w Szczecinie z dnia 23 czerwca 2016 r., VIII Gz 63/16, System Analizy Orzeczeń Sądowych nr 231715.

33 Wraz z wejściem w życie ustawy nowelizującej prawo upadłościowe z dnia 29 sierpnia 2014 r. wprowadzono zasadę, że „postępowanie upadłościowe wobec konsumenta należy prowadzić tak, aby umożliwić umorzenie zobowiązań upadłego niewykonanych w postępowaniu upadłościowym, a jeśli jest to możliwe — zaspokoić roszczenia wierzycieli w jak najwyższym stopniu".

34 Druk nr 2824, s. 109. 
Założenia ustawodawcy zostały odzwierciedlone w art. $491^{4}$ p.u. w brzmieniu obowiązującym od 31 grudnia 2014 r., wyliczającym warunki, w których sąd obowiązany jest oddalić wniosek o ogłoszenie upadłości konsumenckiej. Należy przypomnieć, że postanowienia tegoż artykułu w większości mają charakter zbieżny z przesłankami oddalenia wniosku oddłużeniowego na gruncie postępowania wobec osoby fizycznej prowadzącej działalność gospodarczą i, podobnie, oparte są na modelu rzetelnego i uczciwego dłużnika. W piśmiennictwie podkreśla się, że względna spójność przesłanek z art. 369 p.u. i art. $491^{4}$ p.u. jest szczególnie uzasadniona $\mathrm{z}$ systemowego punktu widzenia.

Zdaniem SO w Bydgoszczy ${ }^{35}$,instytucja upadłości konsumenckiej według zamierzeń ustawodawcy jest procedurą oddłużeniową mającą pomóc dłużnikowi, który swej niewypłacalności nie spowodował »umyślnie lub wskutek rażącego niedbalstwa« w rozpoczęciu na nowo z czystą kartą życia bez długów". W niniejszej sprawie SO nie przychylił się do wniosku dłużnika o ogłoszenie upadłości konsumenckiej z tego względu, że dłużnik przed złożeniem wniosku nie podejmował racjonalnych decyzji związanych z jego sytuacją majątkową, i tym samym nie spełniał kryterium tak zwanej moralności płatniczej dłużnika. SO podkreślił również, że

zasada oddłużenia osób nieprowadzących działalności gospodarczej ma [...] prowadzić do ograniczenia wykluczenia społecznego [...] oraz umożliwienie reintegracji w legalnym obrocie gospodarczym i ograniczenie tzw. szarej strefy. Zasada „prymatu” funkcji oddłużeniowej nie jest jednak absolutna.

W dalszej części uzasadnienia sąd szczegółowo omawia znacznie „umyślności” i „rażącego niedbalstwa" 36 , przyjmując, że obie przesłanki powinny być badane na dwóch płaszczyznach — subiektywnej i obiektywnej ${ }^{37}$, a ocenie sądu podlegają zarówno skutki w sferze prawnej, jak i zachowania czysto faktyczne.

Abstrahując jednak od oceny generalnej „rzetelnego wizerunku” dłużnika, sąd ma obowiązek oddalić wniosek o ogłoszenie upadłości, jeśli jest spełniony jeden z warunków wymienionych $\mathrm{w}$ art. $491^{4}$ ust. 2 p.u. Dla byłego przedsiębiorcy szczególne znaczenie ma $\mathrm{w}$ tym wypadku konieczność oddalenia wniosku o upadłość konsumencką, jeśli w okresie dziesięciu lat przed dniem zgłoszenia wniosku dłużnik, mając taki obowiązek, wbrew przepisom ustawy nie zgłosił w terminie wniosku o ogłoszenie upadłości. Tym samym ustawodawca zabez-

35 Postanowienie SO w Bydgoszczy z dnia 28 listopada 2016 r., VIII Gz 182/16, System Analizy Orzeczeń Sądowych nr 267949.

36 Zob. także postanowienie SO w Częstochowie z dnia 25 listopada 2016 r., V Gz 209/16, System Analizy Orzeczeń Sądowych nr 261155, w którym sąd wskazuje, że „,przepis art. $491^{4}$ ust. 1 p.u. przewiduje dwie postaci winy, tj. winę umyślną i nieumyślną w postaci rażącego niedbalstwa”.

37 Elementem obiektywnym jest działanie lub zaniechanie sprzeczne z prawem lub dobrym obyczajami (bezprawność), elementem subiektywnym zaś jest nastawienie dłużnika do swojego zachowania na etapie ich dokonywania. Zob. postanowienie SO w Bydgoszczy z dnia 28 listopada 2016 r., VIII Gz 182/16, System Analizy Orzeczeń Sądowych nr 267949. 
pieczył się przed drugą z wymienionych na wstępie sytuacji, w której osoby niewypłacalne wyrejestrują działalność z CEIDG bez przeprowadzenia postępowania upadłościowego, po to by skorzystać $z$ tańszej i przystępniejszej procedury, gwarantującej pełne umorzenie zobowiązań ${ }^{38}$. Natomiast, jak wynika z przytoczonego przepisu, jeśli przedsiębiorca indywidualny w ogóle zaniechał złożenia wniosku bądź też złożył wniosek spóźniony, możliwość oddłużenia w tak zwanej upadłości konsumenckiej w praktyce będzie co do zasady wykluczona. Przesłanką mitygującą tak skrajne podejście jest kilkakrotnie pojawiająca się $\mathrm{w}$ ustawie klauzula „względów słuszności” czy „względów humanitarnych”. Na marginesie należy zauważyć, że sformułowanie art. $491^{4}$ p.u. narzuca wniosek o braku możliwości zastosowania wskazanej klauzuli w wypadku zaistnienia „umyślności” lub „rażącego niedbalstwa” dłużnika. Jedynie przesłanki negatywne wymienione w ust. 2-4 mogą zostać złagodzone, gdy jest to uzasadnione względami o charakterze społecznym, słusznościowym czy humanitarnym ${ }^{39}$. Dodatkowo warto pamiętać, że obowiązek udokumentowania okoliczności uzasadniających powołanie się na wskazaną klauzulę leży po stronie dłużnika, po stronie zaś sądu leży obowiązek wszechstronnego zbadania okoliczności sprawy i oceny, czy względy słuszności lub względy humanitarne przemawiają za przeprowadzeniem postępowania. Praktyka pokazuje, że sądy ową przesłankę starają się interpretować wąsko, dając pierwszeństwo tezie, że co do zasady dłużnik powinien ponieść konsekwencje swojego negatywnego postępowania, często nawet mimo niewątpliwie trudnej sytuacji osobistej ${ }^{40}$.

\section{Podsumowanie}

Reasumując, umorzenie całości lub części niezaspokojonych zobowiązań pozostałych po zlikwidowaniu całego majątku dłużnika w postępowaniu upadłościowym jest możliwe względem upadłych osób fizycznych prowadzących działalność gospodarczą (przedsiębiorców wpisanych do CEIDG), o ile spełniają one określone kryteria łącznie składające się na obraz „rzetelnego dłużnika”. Obostrzenia stawiane przed dłużnikami mają na celu przede wszystkim ochronę rynku przed niekontrolowanym zadłużaniem się z nadzieją na późniejsze oddłużenie. W wypadku wystąpienia negatywnej przesłanki uniemożliwiającej

38 Inne zalety upadłości konsumenckiej to w szczególności: możliwość oddłużenia wobec jednego wierzyciela, tzw. przywilej socjalny (czasowe wsparcie w zaspokojeniu potrzeb mieszkaniowych) czy też szerszy zakres oddłużenia.

39 Zob. postanowienie SO w Częstochowie z dnia 25 listopada 2016 r., V Gz 209/16, System Analizy Orzeczeń Sądowych nr 261155.

40 Ibidem. W uzasadnieniu sąd podkreślił, że przeprowadzenie upadłości konsumenckiej w stosunku do byłego przedsiębiorcy nie może mieć miejsca z powołaniem się na klauzulę względów słuszności i względów humanitarnych, jeśli „nie jest to z punktu widzenia przyjętych norm społecznych moralnie zasadne". 
oddłużenie po stronie dłużnika leży obowiązek podniesienia szczególnych okoliczności pozwalających na oddłużenie w trybie art. 369 p.u.

Obecna linia orzecznicza powinna stanowić przestrogę dla niewypłacalnych jednoosobowych przedsiębiorców, którzy nie składając wniosku o upadłość jako przedsiębiorca, liczą na dobrodziejstwo oddłużenia na drodze upadłości konsumenckiej. W szczególności sądy nieprzychylnym okiem oceniają postępowanie dłużnika, który ze świadomością popadł w spiralę zadłużenia, zaciągając kolejne kredyty na spłatę wcześniejszych zobowiązań i tym samym zwiększając swoje zadłużenie mimo braku pozytywnych prognoz na przyszłość co do zyskowności działalności (multiplikowanie zobowiązań kredytowych). Jak przyjął SO w Częstochowie, ,takie działania nie mogą z punktu widzenia zasad słuszności zasługiwać na akceptację"41. Brak bądź zwlekanie ze złożeniem wniosku o upadłość przedsiębiorcy należy oceniać nagannie, tym bardziej że narastanie zadłużenia w postaci odsetek uznaje się za szczególnie krzywdzące z perspektywy ogółu wierzycieli $^{42}$. Niejednokrotnie przypomina o tym orzecznictwo, wskazując, że „art. $491^{4}$ ust. 2 pkt 3 p.u. ma w założeniu pozbawiać przedsiębiorcę, który nie dopełnił ww. obowiązków, możliwości umorzenia zobowiązań z tytułu prowadzonej działalności gospodarczej w trybie przepisów konsumenckich43. Zakaz ten, choć interpretowany wysoce rygorystycznie, nie ma jednak charakteru absolutnego.

Oznacza to, że powoływanie się na tak zwaną klauzulę rozsądku, czy to z art. 369 p.u., czy też art. $491^{4}$ p.u., co do zasady, nie może sanować ciągłego zwiększania zadłużenia, chyba że przemawiają za tym ważne względy społeczne, słusznościowe czy humanitarne - wynikające $\mathrm{z}$ aktualnej sytuacji danego dłużnika. Przede wszystkim muszą to być zdarzenia nadzwyczajne i niezależne od samego dłużnika. I choć obecnie klauzule względów słuszności i względów humanitarnych nie są wolne od wątpliwości interpretacyjnych, sądy stosują je z dużą ostrożnością, w przeważającej większości przypadków odmawiając oddłużenia obecnego lub byłego przedsiębiorcy (konsumenta) i odpowiadając się za interpretacją in favorem creditotum ${ }^{44}$.

${ }^{41}$ Postanowienie SO w Częstochowie z dnia 30 czerwca 2016 r., V Gz 102/16, System Analizy Orzeczeń Sądowych nr 247487.

42 Tak przyjął SO w Bydgoszczy w postanowieniu z dnia 12 maja 2016 r., VIII Gz 42/16, System Analizy Orzeczeń Sądowych nr 225902. Sąd zwrócił uwagę, że nieterminowe ogłoszenie upadłości przedsiębiorcy faworyzuje tych z wierzycieli, którzy jako pierwsi zdecydowali się egzekwować swoje należności.

43 Ibidem.

44 Łac. na korzyść wierzycieli. O konieczności ścisłej interpretacji przesłanek warunkujących oddłużenie w świetle konstytucyjnej zasady ochrony praw majątkowych m.in. S. Gurgul, op. cit., s. 764 . 


\section{Bibliografia}

Adamus R., Komentarz do art. 8 p.u., [w:] Prawo upadtościowe i naprawcze, red. A. Witosz, A.J. Witosz, Warszawa 2014.

Adamus R., Prawo upadtościowe. Komentarz, Warszawa 2016.

Gurgul S., Prawo upadtościowe. Prawo restrukturyzacyjne. Komentarz, Warszawa 2016.

Lewandowski R., Wołowski P., Prawo upadłościowe i naprawcze, Warszawa 2011.

Zimmerman P., Prawo upadłościowe. Prawo restrukturyzacyjne. Komentarz, Warszawa 2016.

\section{Akty prawne}

Druk nr 2824 z dnia 9 października 2014 r. Rządowy projekt ustawy — Prawo restrukturyzacyjne wraz z uzasadnieniem.

Ustawa z dnia 23 kwietnia 1964 r. Kodeks cywilny, tekst jedn. Dz.U.2017.459.

Ustawa z dnia 6 czerwca 1997 r. Kodeks karny, tekst jedn. Dz.U.2016.1137 ze zm.

Ustawa z dnia 15 września 2000 r. Kodeks spółek handlowych, tekst jedn. Dz.U.2016.1578.

Ustawa z dnia 28 lutego 2003 r. Prawo upadłościowe, tekst jedn. Dz.U.2016.2171.

Ustawa z 15 maja 2015 r. Prawo restrukturyzacyjne, tekst jedn. Dz.U.2016.1574 ze zm.

Ustawa z dnia 30 września 2014 r. o zmianie ustawy - Prawo upadłościowe i naprawcze, ustawy o Krajowym Rejestrze Sądowym oraz ustawy o kosztach sądowych w sprawach cywilnych, Dz.U.2014.1306.

Postanowienie SN z dnia 23 marca 2006 r., IV CSK 35/2005, OSNC 2007/1/14.

Postanowienie SN z dnia 29 października 2008 r., IV CSK 239/2008, OSNC-ZD 2009/3/67.

Postanowienie SO w Bydgoszczy z dnia 12 maja 2016 r., VIII Gz 42/16, System Analizy Orzeczeń Sądowych nr 225902.

Postanowienie SO w Bydgoszczy z dnia 28 listopada 2016 r., VIII Gz 182/16, System Analizy Orzeczeń Sądowych nr 267949

Postanowienie SO w Częstochowie z dnia 30 czerwca 2016 r., V Gz 102/16, System Analizy Orzeczeń Sądowych nr 247487.

Postanowienie SO w Częstochowie z dnia 15 lipca 2016 r., V Gz 123/16, System Analizy Orzeczeń Sądowych nr 247488.

Postanowienie SO w Częstochowie z dnia 25 listopada 2016 r., V Gz 209/16, System Analizy Orzeczeń Sądowych nr 261155.

Postanowienie SO w Szczecinie z dnia 23 czerwca 2016 r., VIII Gz 63/16, System Analizy Orzeczeń Sądowych nr 231715.

Wyrok SN z dnia 26 stycznia 2006 r., V CSK 90/2005, Lex nr 195430.

Wyrok SO w Gliwicach z 27 maja 2013 r., X Gz 97/13, niepubl.

Wyrok TK z dnia 4 lipca 2002 r., Dz.U.2002.113.990.

Wyrok WSA w Warszawie z dnia 2 grudnia 2009 r., III SA/Wa 1136/2009, LEX nr 550190.

Zalecenie Komisji z dnia 12 marca 2014 r. w sprawie nowego podejścia do niepowodzenia w działalności gospodarczej i niewypłacalności, Dz. Urz. UE Nr 74, s. 65.

\section{Bankruptcy of a single trader with the possibility of debt relief and consumer bankruptcy of a former entrepreneur - selected issues}

\section{Summary}

In summary, it is possible to cancel all or part of unpaid liabilities remaining after the liquidation of debtor's assets in bankruptcy proceedings in case of natural persons solely carrying out business activities (entrepreneurs entered into CEIDG), provided that they fulfill certain criteria 
combined in the image of a "reliable debtor". The constraints imposed on the said debtors are primarily aimed at protecting the market from uncontrolled indebtedness with the hope of subsequent debt relief. In case of occurrence of one of negative premises preventing the debt from being cancelled, it is the responsibility of the debtor to raise specific circumstances allowing the debt to be exonerated pursuant to Article 369 of Polish Bankruptcy Law.

The current case law should be a warning to insolvent single-person entrepreneurs who, without previous filing for bankruptcy as an entrepreneur, are counting on the benefits of consumer bankruptcy procedure. In particular, the courts with unfavorable eye assess the behaviour of a debtor who is aware of falling into the so-called "debt spiral", borrowing further loans to repay previous liabilities and thereby increasing its debt despite the lack of positive predictions for future profitability (the so-called multiplication of credit liabilities).

As it was admitted by District Court in Czestochowa: "such actions cannot be accepted from the point of view of fairness". A lack of or delay in filing for the insolvency of an entrepreneur should be judged in a more serious manner, especially since the increase in debt in the form of interest is considered to be particularly harmful from the perspective of creditors at large. The said behaviour is often illustrated in case law, e.g.: "Article $491^{4}$ Section 2 Point 3 of Polish Bankruptcy Law is supposed to deprive the trader who did not complete the aforementioned obligations of the possibility of cancelling debts arising out of business activities in the mode of consumer regulations". Yet, this inhibition, though interpreted highly rigorously, is not absolute.

This means that the reference to the so-called clause of reason, whether through Article 369 or Article $491^{4}$ of Polish Bankruptcy Law, as a rule, cannot sanction continuous indebtedness, unless there are strong social, fair, or humanitarian reasons for it - due to the current situation of the debtor in question. Above all, the said reasons must be extraordinary and independent of the debtor. Additionally, the clauses of equity and humanitarian reasons are not free of interpretation doubts, what makes the courts use them cautiously, in the overwhelming majority of cases denying the debt of the present or former entrepreneur (consumer) to be cancelled and approving the interpretation in favorem creditotum. 